\title{
PENGARUH PEMBANGUNAN PRASARANA PARIWISATA TERHADAP PENINGKATAN KUNJUNGAN WISATAWAN PADA OBYEK WISATA DANAU LINTING KABUPATEN DELI SERDANG
}

\author{
Munifah Suryani Harahap, Edi Winata, M. Abbas \\ Alumni Sekolah Tinggi Ilmu Manajemen Sukma \\ Program studi Manajemen, Sekolah Tinggi Ilmu Manajemen \\ ediwinatarivai11960@gmail.com, abbashmad990@gmail.com
}

\begin{abstract}
The purpose of this study is to determine whether there is influence of the development of tourism infrastructure to increase tourist visits on the attractions of Lake Linting Deli Serdang District. The sample of this research is 133 visitor of Lake Linting, sampling using random sampling is sample determination giving equal opportunity to every member of population to be sampled. Data analysis using Simple Regression test with model accuracy (classic assumption test), hypothesis test using coefficient of determination test (R2) and partial test ( $t$ test), while data processing using SPSS 20. The result showed that the development of tourism infrastructure able to explain its existence to Variable of tourist visit, have positive and significant influence to tourist visit.

Keywords: Tourism infrastructure, tourist visit, and Linting Lake
\end{abstract}

\section{PENDAHULUAN}

Daerah yang maju di sektor pariwisata dapat dipastikan masyarakatnya sejahtera, sebab peranan pariwisata dalam pembangunan ekonomi sudah tidak diragukan lagi. Untuk menghasilkan obyek wisata yang unggul tidak terlepas dari prasarana pariwisata pada obyek wisata itu sendiri. Pembangunan Prasarana Pariwisata yang diperlukan di Danau Linting selama ini terus dilakukan Pemerintah Kabupaten Deli Serdang guna menjadikan Danau Linting sebagai Objek Wisata yang bagus, karena pemerintah optimis dengan prasarana yang baik dan lengkap maka kunjungan wisatawan juga semakin meningkat. Sehingga memberi dampak positif bagi perekonomian masyarakat, khususnya masyarakat Deli Serdang. Tabel di bawah ini menunjukkan peningkatan jumlah kunjungan wisatawan yang datang ke Objek Wisata Danau Linting.

\section{Perumusan Masalah}

Perumusan masalah penelitian ini yaitu apakah ada pengaruh pembangunan prasarana pariwisata terhadap peningkatan kunjungan wisatawan pada obyek wisata Danau Linting Kabupaten Deli Serdang?

\section{Batasan Masalah}

Penelitian ini hanya dibatasi pada pengaruh pembangunan prasarana terhadap peningkatan kunjungan wisatawan yang berkunjung ke Danau Linting pada tahun 2013 sampai dengan tahun 2016.

\section{Tujuan Penelitian}

Adapun tujuan dari penelitian ini adalah untuk mengetahui pengaruh pembangunan prasarana pariwisata terhadap peningkatan jumlah kunjungan wisatawan pada obyek wisata Danau Linting Kabupaten Deli Serdang.

\section{Manfaat Penelitian}

Manfaat dari penelitian ini adalah sebagai berikut:

1. Bagi peneliti, menambah pengetahuan dan wawasan peneliti khususnya berkenaan dengan pengaruh pembangunan prasarana pariwisata terhadap kunjungan wisatawan pada obyek wisata Danau Linting Kabupaten Deli Serdang;

2. Bagi Dinas Pariwisata Kabupaten Deli Serdang, sebagai bahan masukan mengenai pengaruh pembangunan prasarana pariwisata terhadap kunjungan wisatawan pada obyek wisata Danau Linting Kabupaten Deli Serdang yang berkaitan dengan kesejahteraan masyarakat, khususnya masyarakat Kabupaten Deli Serdang; 
3. Bagi STIM Sukma, sebagai tambahan hasil penelitian yang dapat digunakan sebagai bahan rujukan dan dikembangkan lebih lanjut;

4. Bagi peneliti selanjutnya, sebagai bahan referensi khususnya yang berkaitan dengan pembangunan prasarana pariwisata dan kunjungan wisatawan.

\section{METODE PENELITIAN}

\section{Jenis dan Sumber Data}

Data yang digunakan dalam penelitian ini adalah data primer dan data sekunder.

1. Data primer adalah sumber data yang secara langsung memberikan data kepada pengumpul data (Sugyiono, 2012:25). Data primer berupa catatan hasil wawancara yang diperoleh melalui wawancara yang penulis lakukan. Selain itu mengumpulkan data dalam bentuk catatan tentang situasi dan kejadian di perpustakaan.

2. Data sekunder merupakan sumber data yang tidak memberikan informasi secara langsung kepada pengumpul data. Sumber data sekunder ini dapat berupa hasil pengolahan lebih lanjut dari data primer yang disajikan dalam bentuk lain atau orang lain (Sugiyono, 2012:25).

Sumber data yang digunakan yaitu:

1. Data Internal yaitu data yang didapat dari tempat penelitian dengan cara membagikan dan menggumpulkan kembali kuesioner kepada pengunjung Danau Linting Kabupaten Deli Serdang. Dimana data tersebut merupakan data mentah dan harus diolah sebelum dituangkan kedalam skripsi.

2. Data Eksternal adalah data yang didapat dari luar tempat penelitian seperti internet dan perpustakaan.

\section{Populasi dan Sampel}

Populasi adalah keseluruhan atau totalitas objek yang diteliti ciri-ciri populasi disebut parameter. Oleh karena itu, populasi juga sering diartikan sebagai kumpulan objek penelitian dari mana data akan dijaring atau dikumpulkan (Neolakan, 2014:41). Adapun jumlah populasi dalam penelitian ini sebanyak 200 orang.

Sampel adalah sebagian unsur populasi yang dijadikan objek penelitian. Sampel atau sering juga disebut contoh adalah wakil dari populasi yang ciri-cirinya akan diungkapkan dan akan digunakan untuk menaksir ciri-ciri populasi (Neolakan, 2014:42). Teknik pengambilan sampel yang digunakan dalam penelitian ini adalah random sampling. Random sampling adalah teknik pengambilan sampel yang memberikan kesempatan yang sama kepada setiap anggota yang ada dalam satu populasi untuk dijadikan sampel. Sampel penelitian ini diambil dengan menggunakan teknik slovin dengan rumus:

keterangan:

$$
\mathrm{n}=\frac{\mathrm{N}}{1+\mathrm{Ne}^{2}}
$$

n: sampel

$\mathrm{N}$ : populasi

e : perkiraan tingkat kesalahan

dengan jumlah populasi 200 orang dan perkiraan tingkat kesalahan 5\% maka didapat jumlah sampel sebanyak 33 orang.

\section{Metode Pengumpulan Data}

Metode pengumpulan data yang digunakan dalam penelitian ini sebagai berikut:

1. Studi Dokumentasi: pengumpulan data yang dilakukan dengan mencari informasi berdasarkan dokumen-dokumen Dinas Pariwisata Kabupaten Deli Serdang yang berkaitan dengan penelitian.

2. Kuesioner: metode pengumpulan data dengan membuat daftar pernyataan dalam bentuk angket yang ditujukan kepada responden yang dijadikan sampel.

3. Observasi: pengamatan data melalui pengamatan secara langsung di Danau Linting Kabupaten Deli Serdang.

\section{Defenisi Operasional}


Berdasarkan rumusan masalah, maka variabel-variabel dalam penelitian ini dapat diidentifikasi sebagai berikut:

1. Variabel bebas ( Variabel Independen ) adalah variabel yang mempengaruhi variabel terkait, yang terdiri dari prasarana pariwisata $(\mathrm{X})$;

2. Variabel Terikat (Variabel Dependen) adalah Variabel yang dipengaruhi oleh variabel bebas, yaitu tingkat kunjungan $(\mathrm{Y})$.

Tabel 3.2: Operasionalisasi Variabel Penelitian

\begin{tabular}{|c|c|c|}
\hline Variabel & Defenisi & Indikator \\
\hline $\begin{array}{l}\text { Prasarana } \\
\text { Pariwisata (X) }\end{array}$ & $\begin{array}{l}\text { semua fasilitas yang } \\
\text { memungkinkan proses } \\
\text { perekonomian dapat berjalan } \\
\text { dengan lancar sedemikian } \\
\text { rupa, sehingga dapat } \\
\text { memudahkan manusia untuk } \\
\text { memenuhi kebutuhannnya. } \\
\text { Jadi fungsinya adalah } \\
\text { melengkapi sarana } \\
\text { kepariwisataan, sehingga } \\
\text { dapat memberikan pelayanan } \\
\text { sebagaimana mestinya. }\end{array}$ & $\begin{array}{l}\text { 1. Akses yang memberikan } \\
\text { kemudahan kepada wisatawan } \\
\text { untuk mencapai daerah tujuan } \\
\text { wisata. } \\
\text { 2. Alat transportasi. } \\
\text { 3. Fasilitas keamanan, keuangan, } \\
\text { kesehatan, pusat informasi. } \\
\text { 4. Fasilitas pendukung demi } \\
\text { kelancaran kegiatan pariwisata. }\end{array}$ \\
\hline $\begin{array}{l}\text { Tingkat } \\
\text { Kunjungan } \\
\text { Wisatawan(Y) }\end{array}$ & $\begin{array}{l}\text { orang yang mengadakan } \\
\text { perjalanan dari tempat } \\
\text { kediamannya tanpa menetap } \\
\text { di tempat yang didatanginya } \\
\text { atau hanya untuk sementara } \\
\text { waktu tinggal di tempat yang } \\
\text { didatanginya. }\end{array}$ & $\begin{array}{l}\text { 1. Obyek dan daya tarik wisata } \\
\text { 2. Prasarana dan Sarana } \\
\text { 3. Tata Pelaksanaan: safety, service } \\
\text { and attitude/behavior. }\end{array}$ \\
\hline
\end{tabular}

Sumber: Agusbushro et al (2014:122), Ridwan (2012:67), Soekadijo dalam Taufik (2016)

\section{Uji Validitas dan Reliabilitas}

Menurut (Sugiyono, 2016:348) "uji validitas adalah pengujian yang dilakukan terhadap isi suatu instrument, dengan tujuan untuk mengukur ketepatan insturmen yang digunakan dalam suatu penelitian". Dikatakan valid jika nilai $r_{\text {hitung }}>r_{\text {tabel }}$ dan dikatakan tidak valid jika nilai $r_{\text {hitung }}<r_{\text {tabel. }}$.

Menurut (Sugiyono, 2016:348) "uji reliabilitas adalah proses pengukuran terhadap ketepatan (konsisten) dari suatu insturmen". Dikatakan reliable jika nilai crombach alfa $>0,6$ dan dikatakan tidak reliable jika nilai crombach alfa $<0,6$.

\section{Metode Analisis Data}

Metode analisis data yang digunakan dalam penelitian ini adalah metode deskriptif kuantitatif,sedangkan model analisis yang digunakan dalam penelitian ini adalah Regresi linear sederhana, dengan model persamaan:

di mana:

$$
\mathbf{Y}=\mathbf{a}+\mathbf{b} \mathbf{X}+\mathbf{e}
$$

$\mathrm{Y}=$ tingkat kunjungan wisatawan

$\mathrm{X}=$ prasarana pariwisata

$\mathrm{b}=$ koefisien regresi variabel

$\mathrm{e}=$ Error of term (variabel yang tidak diteliti)

\section{Kerangka Berfikir}

Prasarana adalah semua fasilitas yang memungkinkan proses perekonomian dapat berjalan dengan lancar sedemikian rupa, sehingga dapat memudahkan manusia untuk memenuhi kebutuhannya. Jadi fungsinya adalah melengkapi sarana kepariwisataan, sehingga dapat memberikan pelayanan sebagaimana mestinya. Wisatawan adalah orang yang mengadakan perjalanan dari tempat kediamannya tanpa menetap di tempat yang didatanginya atau hanya untuk sementara waktu tinggal di tempat yang didatanginya. 


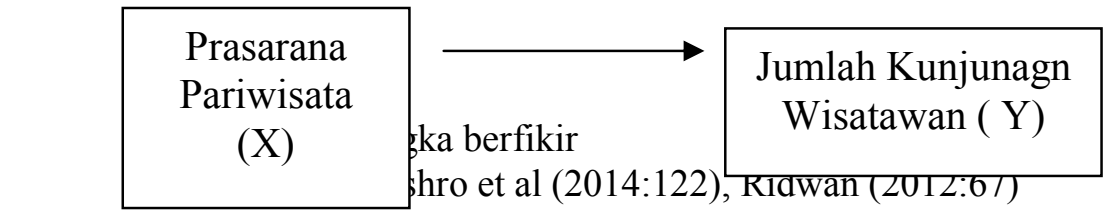

Hipotesis

Menurut Sugiyono (2016:84). Hipotesis diartikan sebagai jawaban sementara terhadap rumusan masalah penelitian. Rumusan masalah tersebut bisa berupa pernyataan tentang hubungan dua variabel atau lebih, perbandingan (komparasi), atau variabel mandiri (deskripsi). Berdasarkan pengertian di atas, maka hipotesis penelitian ini adalah:

$\mathrm{H}_{0}$ : Secara parsial pembangunan prasarana pariwisata berpengaruh tidak signifikan terhadap peningkatan Kunjungan Wisatawan pada Objek Wisata Danau Linting Kabupaten Deli Serdang.

$\mathrm{H}_{1}$ : Secara parsial pembangunan prasarana pariwisata berpengaruh signifikan terhadap peningkatan Kunjungan Wisatawan pada Objek Wisata Danau Linting Kabupaten Deli Serdang.

\section{Pengujian Hipotesis}

1. Koefisien Determinasi $\left(\mathrm{R}^{2}\right)$ untuk mengukur seberapa besar kemampuan model dalam menerangkan variable terikat. Semakin besar nilai koefisien (mendekati satu) maka dapat dikatakan bahwa ada pengaruh pada variable bebas $(\mathrm{X})$ terhadap variable terikat $(\mathrm{Y})$.

2. Uji persial (uji t) bertujuan untuk melihat pengaruh pembangunan prasarana pariwisata secara parsial terhadap peningkatan jumlah kunjungan wisatawan, dengan kriteria:

a. Jika $t_{\text {hitung }}<t_{\text {tabel }}$, maka $\mathrm{H}_{0}$ diterima, $\mathrm{H}_{1}$ ditolak, artinya secara parsial penelitian ini tidak pengaruh.

b. Jika $t_{\text {hitung }}>t_{\text {tabel }}$, maka $\mathrm{H}_{0}$ ditolak, $\mathrm{H}_{1}$ diterima, artinya secara parsial penelitian ini ada pengaruh.

\section{HASIL DAN PEMBAHASAN \\ Uraian Tugas}

1. Kepala Dinas Kepemudaan, Olahraga, Kebudayaan dan Pariwisata Mempunyai tugas pokok membantu Bupati melaksanakan urusan pemerintahan bidang Kepemudaan, Olahraga, Kebudayaan dan Pariwisata yang menjadi kewenangan daerah dan tugas pembantuan yang diberikan kepada Kabupaten. Fungsi Kepala Dinas kepemudaan, Olahraga, Kebudayaan dan Pariwisata Kabupaten Deli Serdang antara lain:

a. Perumusan kebijakan di bidang Kepemudaan, Olahraga, Kebudayaan dan Pariwisata;

b. Pelaksanaan kebijakan sesuai dengan bidang Kepemudaan, Olahraga, Kebudayaan dan Pariwisata;

c. Pelaksanaan evaluasi dan pelaporan sesuai dengan bidang Kepemudaan, Olahraga, Kebudayaan dan Pariwisata;

d. Pelaksanaan administrasi dinas sesuai dengan bidang Kepemudaan, Olahraga, Kebudayaan dan Pariwisata; dan

e. Pelaksanaan fungsi lain yang diberikan oleh bupati terkait dengan tugas dan fungsinya.

\section{Sekretaris}

Mempunyai tugas pokok membantu Kepala Dinas dalam melaksanakan teknis dan administratif serta koordinasi pelaksanaan tugas di lingkungan dinas. Fungsi Sekretaris antara lain:

a. Perumusan rencana program dan kegiatan kesekretariatan.

b. Perumusan kebijakan, pedoman, standarisasi, pembinaan dan pengendalian administrasi umum, kepegawaian, keuangan serta perencanaan program.

c. Pengkoordinasian penyusunan rencana program dan kegiatan disetiap bidang sesuai dengan peraturan yang berlaku.

d. Pengelolaan urusan administrasi umum dan kepegawaian, keuangan, penyusunan program, evaluasi dan pelaporan penyelenggaraan tugas-tugas bidang secara terpadu;

e. Mengendalikan urusan administrasi umum, kepegawaian, keuangan, penyusunan program serta evaluasi dan program;

Sekretaris membawahi: 
- Kepala Sub Bagian Umum, yang bertugas membantu sekretaris mengkoordinasikan kegiatan pada Dinas Kepemudaan Olahraga, Kebudayaan dan Pariwisata dalam pengelolaan administrasi umum, kepegawaian dan perlengkapan;

- Kepala Sub Bagian Perencanaan Program, yang bertugas membantu sekretaris melaksanakan pengelolaan administrasi perencanaan program;

- Kepala Sub Bagian Keuangan, yang bertugas membantu sekretaris melaksanakan pengelolaan administrasi keuangan;

3. Kepala Bidang Kepemudaan

Mempunyai tugas pokok membantu Kepala Dinas dalam melaksanakan tugas pada lingkup bidang kepemudaan. Fungsi Kepala Bidang Kepemudaan antara lain:

a. Perumusan kebijakan di bidang pemberdayaan pemuda, pengembangan pemuda, infrastruktur dan kemitraan pemuda;

b. Penyusunan program kerja di bidang Kepemudaan yang meliputi pemberdayaan pemuda, pengembangan pemuda, infrastruktur dan kemitraan pemuda;

c. Penyusunan norma, standar operasional prosedur (SOP) dan kriteria di bidang pemberdayaan pemuda, pengembangan pemuda, infrastruktur dan kemitraan pemuda;

d. Pemberian bimbingan teknis dan supervisi di bidang pemberdayaan pemuda, pengembangan pemuda, infrastruktur dan kemitraan pemuda;

e. Pemantauan, analisis, evaluasi dan pelaporan di bidang pemberdayaan pemuda, pengembangan pemuda, infrastruktur dan kemitraan pemuda.

Kepala Bidang Kepemudaan membawahi:

- Kepala Seksi Pemberdayaan Pemuda bertugas membantu kepala bidang Kepemudaan dalam melaksanakan tugas pada lingkup Seksi Pemberdayaan Pemuda.

- Kepala Seksi Pengembangan Pemuda bertugas membantu kepala bidang Kepemudaan dalam melaksanakan tugas pada lingkup Seksi Pengembangan Pemuda.

- Kepala Seksi Infrastruktur dan Kemitraan Pemuda bertugas membantu kepala bidang Kepemudaan dalam melaksanakan tugas pada lingkup Seksi Infrastruktur dan Kemitraan Pemuda.

4. Kepala Bidang Olahraga

Mempunyai tugas pokok membantu Kepala Dinas dalam melaksanakan tugas pada Bidang Olahraga. Fungsi Kepala Bidang Olahraga antara lain:

a. Perumusan kebijakan di bidang pembudayaan olahraga, peningkatan prestasi olahraga, infrastruktur dan kemitraan olahraga:

b. Penyusunan program kerja di bidang olahraga yang meliputi pembudayaan olahraga, peningkatan prestasi olahraga, infrastruktur dan kemitraan olahraga:

c. Penyusunan norma, standar operasional prosedur (SOP) dan criteria di bidang pembudayaan olahraga, peningkatan prestasi olahraga, infrastruktur dan kemitraan olahraga;

d. Pemberian bimbingan teknis dan supervisi di bidang pembudayaan olahraga, peningkatan prestasi olahraga, infrastruktur dan kemitraan olahraga; dan

e. Pemantauan, analisis, evaluasi dan pelaporan di bidang pembudayaan olahraga, peningkatan prestasi olahraga, infrastruktur dan kemitraan olahraga.

Kepala Bidang Olaharaga membawahi:

- Kepala Seksi Pembudayaan Olahraga bertugas membantu kepala bidang Olahraga dalam melaksanakan tugas pada lingkup Seksi Pembudayaan Olahraga.

- Kepala Seksi Peningkatan Prestasi Olahraga bertugas membantu kepala bidang Olahraga dalam melaksanakan tugas pada lingkup Seksi Peningkatan Prestasi Olahraga.

- Kepala Seksi Infrastruktur dan Kemitraan Olahraga bertugas membantu kepala bidang Olahraga dalam melaksanakan tugas pada lingkup Seksi Infrastruktur dan Kemitraan Olahraga.

5. Kepala Bidang Kebudayaan

Mempunyai tugas pokok membantu Kepala Dinas dalam melaksanakan tugas pada lingkup bidang Kebudayaan. Fungsi Kepala Bidang Kebudayaan antara lain: 
a. Perumusan bahan koordinasi pelaksanaan kebijakan di bidang pengelolaan cagar budaya, pengelolaan museum kabupaten, pembinaan sejarah, pelestarian tradisi, pembinaan komunitas dan lembaga adat, dan pembinaan kesenian;

b. Perumusan bahan pengelolaan dan pembinaan di bidang cagar budaya, pengelolaan museum kabupaten, pembinaan sejarah, pelestarian tradisi, pembinaan komunitas dan lembaga adat, dan pembinaan kesenian;

c. Penyusunan bahan penetapan cagar budaya dan pengelolaan cagar budaya peringkat kabupaten;

d. Perumusan bahan pelestarian tradisi yang masyarakat penganutnya dalam daerah kabupaten;

e. Perumusan bahan pembinaan komunitas dan lembaga adat dan kesenian yang masyarakat penganutnya dalam daerah kabupaten;

Kepala Bidang kebudayaan membawahi:

- Kepala Seksi Cagar Budaya dan Museum bertugas membantu Kepala Bidang Kebudayaan dalam melaksanakan tugas pada lingkup Seksi Cagar Budaya dan Museum.

- Kepala Seksi Sejarah dan Tradisi bertugas membantu Kepala Bidang Kebudayaan dalam melaksanakan tugas pada lingkup Seksi Sejarah dan Tradisi.

- Kepala Seksi Kesenian bertugas membantu Kepala Bidang Kebudayaan dalam melaksanakan tugas pada lingkup Seksi Kesenian.

6. Kepala Bidang Pemasaran dan Promosi Pariwisata

Mempunyai tugas pokok membantu Kepala Dinas dalam melaksanakan tugas pada lingkup bidang pemasaran dan promosi pariwisata. Fungsi Kepala Bidang Pemasaran dan Promosi Pariwisata antara lain:

a. Perumusan kebijakan di bidang Pemasaran dan Pomosi Pariwisata meliputi pengkajian dan pemasaran pariwisata, promosi pariwisata, pelayanan dan informasi pariwisata;

b. Penyusunan program kerja di bidang Pemasaran dan Pomosi Pariwisata meliputi pengkajian dan pemasaran pariwisata, promosi pariwisata, pelayanan dan informasi pariwisata;

c. Penyusunan norma, standar operasional prosedur (SOP) dan kriteria di bidang Pemasaran dan Pomosi Pariwisata meliputi pengkajian dan pemasaran pariwisata, promosi pariwisata, pelayanan dan informasi pariwisata;

d. Pemberian bimbingan teknis dan supervisi di bidang Pemasaran dan Pomosi Pariwisata meliputi pengkajian dan pemasaran pariwisata, promosi pariwisata, pelayanan dan informasi pariwisata;

e. Pemantauan, analisis, evaluasi dan pelaporan di bidang Pemasaran dan Pomosi Pariwisata meliputi pengkajian dan pemasaran pariwisata, promosi pariwisata, pelayanan dan informasi pariwisata.

Kepala Bidang Pemasaran dan Promosi Pariwisata membawahi:

- Kepala Seksi Pengkajian dan Pemasaran Pariwisata bertugas membantu Kepala Bidang Pemasaran dan Promosi Pariwisata dalam melaksanakan tugas pada lingkup seksi pengkajian dan pemasaran pariwisata.

- Kepala Seksi Promosi Pariwisatabertugas membantu Kepala Bidang Pemasaran dan Promosi Pariwisata dalam melaksanakan tugas pada lingkup seksi Promosi Pariwisata.

- Kepala Seksi Pelayanan dan Informasi Pariwisata bertugas membantu Kepala Bidang Pemasaran dan Promosi Pariwisata dalam melaksanakan tugas pada lingkup seksi Promosi Pariwisata.

7. Kepala Bidang Usaha Kepariwisataan, Sarana dan Prasarana

Mempunyai tugas pokok membantu Kepala Dinas dalam melaksanakan tugas pada lingkup bidang usaha kepariwisataan, sarana dan prasarana. Fungsi Kepala Bidang Usaha Kepariwisataan, Sarana dan Prasarana antara lain:

a. Perumusan bahan kebijakan di bidang Usaha Kepariwisataan, Sarana dan Prasarana meliputi pembinaan usaha kepariwisataan, pengawasan usaha kepariwisataan, dan peningkatan sarana dan prasarana pariwisata; 
b. Perumusan bahan Penyusunan program kerja di bidang Usaha Kepariwisataan, Sarana dan Prasarana meliputi pembinaan usaha kepariwisataan, pengawasan usaha kepariwisataan, dan peningkatan sarana dan prasarana pariwisata;

c. Pelaksanaan norma, standar operasional prosedur (SOP) dan kriteria di bidang Usaha Kepariwisataan, Sarana dan Prasarana meliputi pembinaan usaha kepariwisataan, pengawasan usaha kepariwisataan, dan peningkatan sarana dan prasarana pariwisata;

d. Pemberian bimbingan teknis dan supervisi di bidang Usaha Kepariwisataan, Sarana dan Prasarana meliputi pembinaan usaha kepariwisataan, pengawasan usaha kepariwisataan, dan peningkatan sarana dan prasarana pariwisata;

e. Pemantauan, analisis, evaluasi dan pelaporan di bidang Usaha Kepariwisataan, Sarana dan Prasarana meliputi pembinaan usaha kepariwisataan, pengawasan usaha kepariwisataan, dan peningkatan sarana dan prasarana pariwisata

Kepala Bidang Usaha Kepariwisataan, Sarana dan Prasarana membawahi:

- Kepala Seksi Pembinaan Usaha Kepariwisataan bertugas membantu Kepala Bidang Usaha Kepariwisataan, Sarana dan Prasarana dalam melaksanakan tugas seksi pembinaan usaha kepariwisataan.

- Kepala Seksi Pengawasan Usaha Kepariwisataan bertugas membantu Kepala Bidang Usaha Kepariwisataan, Sarana dan Prasarana dalam melaksanakan tugas seksi Pengawasan Usaha Kepariwisataan.

- Kepala Seksi Sarana dan Prasarana Kepariwisataan bertugas membantu Kepala Bidang Usaha Kepariwisataan, Sarana dan Prasarana dalam melaksanakan tugas seksi Sarana dan Prasarana Kepariwisataan.

\section{Karakterisitik Responden}

Karakteristik responden merupakan identitas responden yang menjadi sampel penelitian. Sampel penelitian sebanyak 133 orang pengunjung Danau Linting yang telah mengisi kuesioner berdasarkan usia dan jenis kelamin. Data karakteristik responden dapat dilihat sebagai berikut:

Tabel 1 Karakteristik responden berdasarkan usia

\begin{tabular}{|l|l|l|}
\hline No & Usia & Jumlah \\
\hline 1 & $18-25$ tahun & 16 \\
\hline 2 & $26-35$ tahun & 10 \\
\hline 3 & $>35$ tahun & 7 \\
\hline \multicolumn{2}{|l|}{ Total } & 33 \\
\hline
\end{tabular}

Dari data diatas diketahui bahwa usia 18-25 tahun lebih banyak dikarenakan usia tersebut adalah responden pelajar dan mahasiswa yang menghabiskan waktu liburannya, selebihnya adalah pekerja dan umum.

Tabel 2 Karakteristik responden berdasarkan jenis kelamin

\begin{tabular}{|l|l|l|}
\hline No & Jenis Kelamin & Jumlah \\
\hline 1 & Laki-laki & 19 \\
\hline 2 & Perempuan & 14 \\
\hline Total & & 33 \\
\hline
\end{tabular}

Dari tabel diatas dapat diketahui jumlah responden laki-laki sedikit lebih banyak jika dibandingkan dengan responden perempuan.

Tabel 3 Karakteristik responden berdasarkan pekerjaan

\begin{tabular}{|l|l|l|}
\hline No & Pendidikan & Jumlah \\
\hline 1 & Pelajar/Mahasiswa & 19 \\
\hline
\end{tabular}




\begin{tabular}{|l|l|c|}
\hline 2 & Karyawan & 7 \\
\hline 3 & Umum & 7 \\
\hline Total & & 33 \\
\hline
\end{tabular}

Tabel diatas menunjukkan bahwa jumlah responden pelajar dan mahasiswa lebih banyak, selebihnya adalah responden status karyawan dan umum.

\section{Deskripsi Data Variabel Prasarana Pariwisata}

Untuk mengukur pembangunan prasarana pariwisata di Danau Linting, digunakan 4 indikator. Berdasarkan pernyataan-pernyataan yang telah dijawab oleh responden, maka dihasilkan data sebagai berikut:

Tabel 4 Rekapitulasi jawaban responden variabel prasarana pariwisata (X)

\begin{tabular}{|c|c|c|c|c|c|c|c|c|c|c|c|c|}
\hline \multirow{3}{*}{ No } & \multirow{3}{*}{ Pernyataan } & \multicolumn{10}{|c|}{ Jawaban responden } & \multirow{3}{*}{$\mathrm{Jlh}$} \\
\hline & & \multicolumn{2}{|c|}{$\begin{array}{l}\text { Sangat } \\
\text { setuju }\end{array}$} & \multicolumn{2}{|c|}{ Setuju } & \multicolumn{2}{|c|}{$\begin{array}{l}\text { Kurang } \\
\text { setuju }\end{array}$} & \multicolumn{2}{|c|}{$\begin{array}{l}\text { Tidak } \\
\text { setuju }\end{array}$} & \multicolumn{2}{|c|}{$\begin{array}{l}\text { Sangat } \\
\text { tidak } \\
\text { setuju }\end{array}$} & \\
\hline & & $\mathrm{F}$ & $\%$ & $\mathrm{~F}$ & $\%$ & $\mathrm{~F}$ & $\%$ & $\mathrm{~F}$ & $\%$ & $\mathrm{~F}$ & $\%$ & \\
\hline 1 & $\begin{array}{l}\text { Prasarana } \\
\text { Pariwisata } 1\end{array}$ & 3 & $9 \%$ & 26 & $79 \%$ & 4 & $12 \%$ & 0 & $0 \%$ & 0 & $0 \%$ & 33 \\
\hline 2 & $\begin{array}{l}\text { Prasarana } \\
\text { Pariwisata } 2\end{array}$ & 7 & $21 \%$ & 26 & $79 \%$ & 0 & $0 \%$ & 0 & $0 \%$ & 0 & $0 \%$ & 33 \\
\hline 3 & $\begin{array}{l}\text { Prasarana } \\
\text { Pariwisata } 3\end{array}$ & 10 & $30 \%$ & 22 & $67 \%$ & 1 & $3 \%$ & 0 & $0 \%$ & 0 & $0 \%$ & 33 \\
\hline 4 & $\begin{array}{l}\text { Prasarana } \\
\text { Pariwisata } 4\end{array}$ & 3 & $9 \%$ & 26 & $79 \%$ & 4 & $12 \%$ & 0 & $0 \%$ & 0 & $0 \%$ & 33 \\
\hline 5 & $\begin{array}{l}\text { Prasarana } \\
\text { Pariwisata } 5\end{array}$ & 7 & $21 \%$ & 26 & $79 \%$ & 0 & $0 \%$ & 0 & $0 \%$ & 0 & $0 \%$ & 33 \\
\hline 6 & $\begin{array}{l}\text { Prasarana } \\
\text { Pariwisata } 6\end{array}$ & 10 & $30 \%$ & 22 & $67 \%$ & 1 & $3 \%$ & 0 & $0 \%$ & 0 & $0 \%$ & 33 \\
\hline 7 & $\begin{array}{l}\text { Prasarana } \\
\text { Pariwisata } 7\end{array}$ & 3 & $9 \%$ & 26 & $79 \%$ & 4 & $12 \%$ & 0 & $0 \%$ & 0 & $0 \%$ & 33 \\
\hline 8 & $\begin{array}{l}\text { Prasarana } \\
\text { Pariwisata } 8\end{array}$ & 7 & $21 \%$ & 26 & $79 \%$ & 0 & $0 \%$ & 0 & $0 \%$ & 0 & $0 \%$ & 33 \\
\hline 9 & $\begin{array}{l}\text { Prasarana } \\
\text { Pariwisata } 9\end{array}$ & 10 & $30 \%$ & 22 & $67 \%$ & 1 & $3 \%$ & 0 & $0 \%$ & 0 & $0 \%$ & 33 \\
\hline 10 & $\begin{array}{l}\text { Prasarana } \\
\text { Pariwisata } 10\end{array}$ & 3 & $9 \%$ & 26 & $79 \%$ & 4 & $12 \%$ & 0 & $0 \%$ & 0 & $0 \%$ & 33 \\
\hline \multicolumn{2}{|c|}{ Rata-rata } & & $19 \%$ & & $75 \%$ & & $6 \%$ & & $0 \%$ & & $0 \%$ & \\
\hline
\end{tabular}

Pada tabel diatas terlihat bahwa yang menjawab setuju sebanyak $75 \%$, yang menjawab sangat setuju sebanyak 19\%, ini menunjukkan bahwa prasarana pariwisata di danau Linting sesuai dengan kebutuhan wisatawan yaitu akses yang memberikan kemudahan kepada wisatawan, tersedianya alat transportasi, fasilitas keamanan, keuangan, kesehatan, pusat informasi dan fasilitas pendukung demi kelancaran kegiatan pariwisata.

\section{Deskripsi Data Variabel Kunjungan Wisatawan}

Tabel 5 Rekapitulasi jawaban responden variabel tingkat kunjungan (Y)

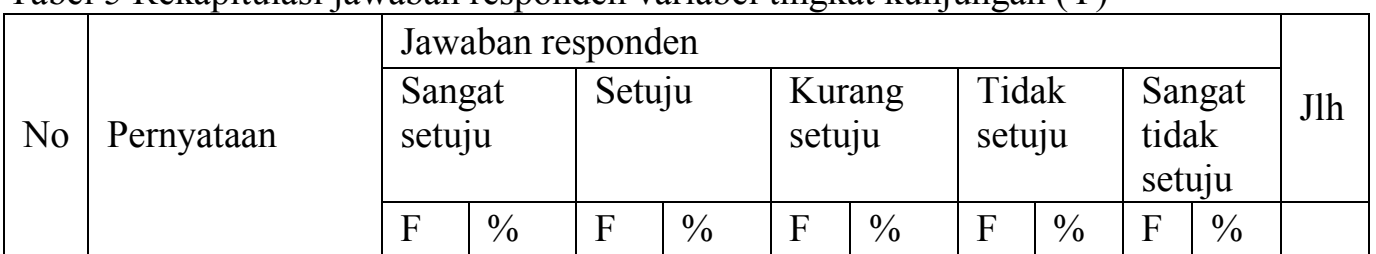




\begin{tabular}{|l|l|l|l|l|l|l|l|l|l|l|l|l|}
1 & $\begin{array}{l}\text { Tingkat } \\
\text { Kunjungan 1 }\end{array}$ & 3 & $9 \%$ & 26 & $79 \%$ & 4 & $12 \%$ & 0 & $0 \%$ & 0 & $0 \%$ & 33 \\
\hline 2 & $\begin{array}{l}\text { Tingkat } \\
\text { Kunjungan 2 }\end{array}$ & 7 & $21 \%$ & 26 & $79 \%$ & 0 & $0 \%$ & 0 & $0 \%$ & 0 & $0 \%$ & 33 \\
\hline 3 & $\begin{array}{l}\text { Tingkat } \\
\text { Kunjungan 3 }\end{array}$ & 10 & $30 \%$ & 22 & $67 \%$ & 1 & $3 \%$ & 0 & $0 \%$ & 0 & $0 \%$ & 33 \\
\hline 4 & $\begin{array}{l}\text { Tingkat } \\
\text { Kunjungan 4 }\end{array}$ & 3 & $9 \%$ & 26 & $79 \%$ & 4 & $12 \%$ & 0 & $0 \%$ & 0 & $0 \%$ & 33 \\
\hline 5 & $\begin{array}{l}\text { Tingkat } \\
\text { Kunjungan 5 }\end{array}$ & 7 & $21 \%$ & 26 & $79 \%$ & 0 & $0 \%$ & 0 & $0 \%$ & 0 & $0 \%$ & 33 \\
\hline 6 & $\begin{array}{l}\text { Tingkat } \\
\text { Kunjungan 6 }\end{array}$ & 10 & $30 \%$ & 22 & $67 \%$ & 1 & $3 \%$ & 0 & $0 \%$ & 0 & $0 \%$ & 33 \\
\hline 7 & $\begin{array}{l}\text { Tingkat } \\
\text { Kunjungan 7 }\end{array}$ & 30 & $91 \%$ & 3 & $9 \%$ & 0 & $0 \%$ & 0 & $0 \%$ & 0 & $0 \%$ & 33 \\
\hline 8 & $\begin{array}{l}\text { Tingkat } \\
\text { Kunjungan 8 }\end{array}$ & 3 & $9 \%$ & 28 & $85 \%$ & 2 & $6 \%$ & 0 & $0 \%$ & 0 & $0 \%$ & 33 \\
\hline 9 & $\begin{array}{l}\text { Tingkat } \\
\text { Kunjungan 9 }\end{array}$ & 7 & $21 \%$ & 26 & $79 \%$ & 0 & $0 \%$ & 0 & $0 \%$ & 0 & $0 \%$ & 33 \\
\hline 10 & $\begin{array}{l}\text { Tingkat } \\
\text { Kunjungan 10 }\end{array}$ & 9 & $27 \%$ & 22 & $67 \%$ & 2 & $6 \%$ & 0 & $0 \%$ & 0 & $0 \%$ & 33 \\
\hline Rata-rata & $27 \%$ & & $69 \%$ & & $4 \%$ & & $0 \%$ & & $0 \%$ & \\
\hline
\end{tabular}

Pada tabel diatas terlihat bahwa yang menjawab sangat setuju sebanyak $27 \%$, yang menjawab setuju sebanyak $69 \%$, ini menunjukkan bahwa wisatawan menjadikan Danau Linting sebagai destinasi pariwisata karena Danau Linting merupakan obyek wisata yang menarik dan didukung prasarana pariwisata yang dan tata kelola yang baik.

Uji Validitas dan Reliabilitas

Uji validitas digunakan untuk melihat ketepatan instrumen yang digunakan dalam penelitian. Instrumen dikatakan valid jika nilai $r_{\text {hitung }}>r_{\text {tabel }}$. Hasil validitas dari setiap instrumen variabel penelitian adalah sebagai berikut:

Tabel 6 Validitas instrumen variabel Prasarana Pariwisata (X)

\begin{tabular}{|c|c|c|c|}
\hline \multirow{2}{*}{ Instrumen } & \multicolumn{2}{|c|}{ Nilai Validitas } & \multirow{2}{*}{ Kesimpulan } \\
\hline & Rhitung & Rtabel & \\
\hline Prasarana pariwisata 1 & 0,734 & \multirow{10}{*}{0.344} & Valid \\
\hline Prasarana pariwisata 2 & 0,757 & & Valid \\
\hline Prasarana pariwisata 3 & 0,761 & & Valid \\
\hline Prasarana pariwisata 4 & 0,734 & & Valid \\
\hline Prasarana pariwisata 5 & 0,757 & & Valid \\
\hline Prasarana pariwisata 6 & 0,761 & & Valid \\
\hline Prasarana pariwisata 7 & 0,734 & & Valid \\
\hline Prasarana pariwisata 8 & 0,757 & & Valid \\
\hline Prasarana pariwisata 9 & 0,761 & & Valid \\
\hline Prasarana pariwisata 10 & 0,734 & & Valid \\
\hline
\end{tabular}

Dari tabel terlihat bahwa pengujian masing-masing instrumen variabel prasarana pariwisata (X) memiliki nilai r-hitung $>0.344$, dengan demikian dapat disimpulkan bahwa secara keseluruhan instrumen pernyataan dari variabel prasarana pariwisata yang digunakan valid.

Tabel 7 Validitas instrumen variabel Tingkat Kunjungan Wisatawan (Y)

\begin{tabular}{|l|c|l|l|}
\hline \multirow{2}{*}{ Instrumen } & \multicolumn{2}{|l|}{ Nilai Validitas } & \multirow{2}{*}{ Kesimpulan } \\
\cline { 2 - 2 } & rhitung & Rtabel & \\
\hline Tingkat kunjungan 1 & $\mathbf{0 , 6 0 5}$ & \multirow{2}{*}{0.344} & Valid \\
\cline { 2 - 2 } Tingkat kunjungan 2 & $\mathbf{0 , 5 5 0}$ & Valid \\
\hline Tingkat kunjungan 3 & $\mathbf{0 , 6 1 5}$ & & Valid \\
\hline
\end{tabular}




\begin{tabular}{|c|c|c|}
\hline Tingkat kunjungan 4 & 0,605 & Valid \\
\hline Tingkat kunjungan 5 & 0,550 & Valid \\
\hline Tingkat kunjungan 6 & 0,615 & Valid \\
\hline Tingkat kunjungan 7 & 0,618 & Valid \\
\hline Tingkat kunjungan 8 & 0,615 & Valid \\
\hline Tingkat kunjungan 9 & 0.550 & Valid \\
\hline Tingkat kunjungan 10 & 0,674 & Valid \\
\hline
\end{tabular}

Dari table terlihat bahwa pengujian masing-masing instrumen variabel tingkat kunjungan wisatawan (Y) memiliki nilai r-hitung $>0.344$, dengan demikian dapat disimpulkan bahwa secara keseluruhan instrumen pernyataan dari variabel tingkat kunjungan wisatawan yang digunakan valid.

Uji reliabilitas dilakukan untuk menjamin instrument yang digunakan merupakan instrument yang handal, konsisten dan stabil jika digunakan secara berulang-ulang pada waktu yang berbedabeda. Instrumen dikatakan reliable jika nilai cronbach alfa hitung > cronbach alfa toleransi (0.6). Hasil pengujian reliabilitas terlihat seperti berikut ini:

Tabel 8 Hasil Reliabilitas Instrumen Penelitian

\begin{tabular}{|l|l|l|l|}
\hline No & Variabel & $\begin{array}{l}\text { Nilai } \\
\text { Cronbach's } \\
\text { Alfa }\end{array}$ & Kesimpulan \\
\hline 1 & Prasarana Pariwisata (X) & $\mathbf{0 , 7 6 9}$ & Reliabel \\
\hline 2 & Tingkat Kunjungan Wisatawan (Y) & $\mathbf{0 , 6 2 7}$ & Reliabel \\
\hline
\end{tabular}

Hasil uji reliabilitas menunjukkan bahwa nilai Cronbach's Alfa seluruh variabel lebih besar dari 0.6, maka dapat disimpulkan bahwa kuesioner penelitian ini dikatakan reliable.

\section{Hasil Uji Regresi Linear Sederhana}

Pengujian ini dilakukan untuk mengetahui pengaruh pembangunan prasarana pariwisata terhadap peningkatan kunjungan wisatawan pada obyek wisata Danau Linting Kabupaten Deli Serdang. Berikut ini tabel hasil pengujian regresi linear sederhana pada masing-masing variabel yaitu: Tabel 9 Hasil Uji Regresi Linear Sederhana

\section{Coefficients $^{\mathrm{a}}$}

\begin{tabular}{|c|c|c|c|c|c|c|}
\hline \multirow{2}{*}{\multicolumn{2}{|c|}{ Model }} & \multicolumn{2}{|c|}{$\begin{array}{l}\text { Unstandardized } \\
\text { Coefficients }\end{array}$} & \multirow{2}{*}{$\begin{array}{l}\text { Standardize } \\
\text { d } \\
\text { Coefficients } \\
\text { Beta }\end{array}$} & \multirow[t]{2}{*}{$t$} & \multirow[t]{2}{*}{ Sig. } \\
\hline & & B & $\begin{array}{l}\text { Std. } \\
\text { Error }\end{array}$ & & & \\
\hline 1 & $\begin{array}{l}\text { (Consta } \\
\text { nt) }\end{array}$ & 11,727 & 2,437 & & 4,813 & ,000 \\
\hline & $\begin{array}{l}\text { Prasara } \\
\text { na }\end{array}$ & ,739 & ,059 & ,914 & 12,561 & ,000 \\
\hline
\end{tabular}

a. Dependent Variable: Kunjungan

Berdasarkan hasil pengujian diatas, maka diperoleh persamaan regresi linear sederhana sebagai berikut:

$\mathrm{Y}=11,727+0,739 \mathrm{X}$

Pada model regresi linear sederhana diperoleh nilai konstanta peningkatan kunjungan wisatawan sebesar 0,739 artinya jika nilai variabel bebas $(\mathrm{X})$ nilainya 0 , maka variabel terikat $(\mathrm{Y})$ nilainya sebesar 11,727 . Koefisien regresi variabel bebas bernilai positif, artinya peningkatan kunjungan wisatawan pada obyek wisata Danau Linting dapat dipengaruhi oleh pembangunan prasarana pariwisata.

\section{Pengujian Hipotesis}

a. Koefisien Determinasi $\left(\mathrm{R}^{2}\right)$ 
Koefisien determinasi bertujuan untuk mengukur berapa besar kemampuan variabel bebas dalam menerangkan variabel terikat. Nilai koefisien determinasi dapat dilihat pada tabel berikut:

Tabel 10 Hasil Uji Koefisiensi Determinasi $\left(\mathrm{R}^{2}\right)$

\section{Model Summary}

\begin{tabular}{|l|r|r|r|r|}
\hline Model & R & $\begin{array}{l}\text { R } \\
\text { Square }\end{array}$ & $\begin{array}{l}\text { Adjusted R } \\
\text { Square }\end{array}$ & $\begin{array}{l}\text { Std. Error of } \\
\text { the Estimate }\end{array}$ \\
\hline 1 &, $\mathbf{9 1 4}^{\mathrm{a}}$ & $\mathbf{, 8 3 6}$ & $\mathbf{8 3 0}$ & $\mathbf{8 8 7 0 6}$ \\
\hline
\end{tabular}

a. Predictors: (Constant), Prasarana

Nilai koefisien determinasi yang diperoleh sebesar 0.836 atau $83,6 \%$ menunjukkan bahwa variabel pembangunan prasarana pariwisata mampu menjelaskan variasi yang terjadi pada peningkatan kunjungan wisatawan pada obyek wisata Danau Linting Kabupaten Deli Serdang, sedangkan sisanya 16,4\% dijelaskan oleh variabel lain yang tidak diteliti dalam penelitian ini.

b. Uji Parsial (Uji t)

Uji parsial (uji t) bertujuan untuk melihat pengaruh pembangunan prasarana pariwisata terhadap peningkatan kunjungan wisatawan, dengan kriteria:

1. Jika $t_{\text {hitung }} \leq t_{\text {tabel }}$ maka $\mathrm{H}_{0}$ diterima, $\mathrm{H}_{1}$ ditolak, artinya secara parsial penelitian ini tidak berpengaruh;

2. Jika $t_{\text {hitung }}>t_{\text {tabel }}$ maka $H_{0}$ ditolak, $H_{1}$ diterima, artinya secara parsial penelitian ini berpengaruh;

Tabel 11 Hasil Uji Parsial (Uji t)

Coefficients $^{\mathrm{a}}$

\begin{tabular}{|c|c|c|c|c|c|c|}
\hline \multirow{2}{*}{\multicolumn{2}{|c|}{ Model }} & \multicolumn{2}{|c|}{$\begin{array}{l}\text { Unstandardized } \\
\text { Coefficients }\end{array}$} & \multirow{2}{*}{\begin{tabular}{|l|} 
Standardize \\
d \\
Coefficients \\
Beta
\end{tabular}} & \multirow[t]{2}{*}{$t$} & \multirow[t]{2}{*}{ Sig. } \\
\hline & & $B$ & \begin{tabular}{|l|} 
Std. \\
Error \\
\end{tabular} & & & \\
\hline \multirow[t]{2}{*}{1} & $\begin{array}{l}\text { (Consta } \\
\text { nt) }\end{array}$ & 11,727 & 2,437 & & 4,813 &, 000 \\
\hline & $\begin{array}{l}\text { Prasara } \\
\text { na }\end{array}$ & ,739 & ,059 & 914 & 12,561 &, 000 \\
\hline
\end{tabular}

a. Dependent Variable: Kunjungan

Berdasarkan tabel tersebut dapat dilihat bahwa: Nilai $t_{\text {hitung }}$ untuk variabel prasarana pariwisata $12,561>\mathrm{t}_{\text {tabel }} 2,040$ dan nilai signifikan $0.000<$ dari alpha (0.05), maka $\mathrm{H}_{0}$ ditolak, dan $\mathrm{H}_{1}$ diterima, dengan demikian secara parsial variabel prasarana pariwisata berpengaruh positif dan signifikan terhadap peningkatan kunjungan wisatawan.

\section{Pembahasan}

Hasil pengujian hipotesis pertama menunjukkan bahwa variabel pembangunan prasarana pariwisata mampu menjelaskan variasi yang terjadi pada peningkatan kunjungan wisatawan pada obyek wisata Danau Linting, ini dibuktikan dengan nilai koefisien determinasi $\left(\mathrm{R}^{2}\right)$ yang diperoleh sebesar 0.836 atau $83,6 \%$, yang artinya pengaruh pembangunan prasarana pariwisata terhadap peningkatan kunjungan wisatawan pada obyek wisata Danau Linting adalah sebesar 83,6\%, sedangkan sisanya sebesar $16,4 \%$ dijelaskan oleh variabel lain yang tidak diteliti dalam penelitian ini.

Hasil pengujian kedua menunjukkan bahwa secara parsial pembangunan prasarana pariwisata berpengaruh terhadap peningkatan kunjungan wisatawan. Hasil penelitian ini sesuai dengan penelitian yang dilakukan oleh Agusbushro et al (2014:122) menyatakan bahwa "Prasarana dan sarana kepariwisataan sesungguhnya merupakan kebutuhan wisatawan yang perlu disiapkan atau disediakan dalam mengembangkan industri pariwisata".

\section{KESIMPULAN}

Berdasarkan hasil penelitian dan pembahasan pada bab sebelumnya, maka dapat disimpulkan:

1. Hasil pengujian diperoleh menunjukkan bahwa semua indikator yang digunakan untuk mengukur variabel-variabel yang digunakan dalam penelitian ini mempunyai koefisien korelasi yang lebih besar dari $r$ standar $=0,344$ (nilai $r$ tabel untuk $n=33$ ) 
2. Hasil pengujian realibilitas didapatkan nilai cronbach alpha variabel prasarana pariwisata (X) sebesar 0,769 > rtabel 0,344 sehingga keputusan uji realibilitas dikatakan reliabel atau handal dan nilai cronbach alpha variabel tingkat kunjungan wisatawan (Y) sebesar 0,627 > rtabel 0,344 sehingga dikatakan juga reliabel atau handal.

3. Hasil pengujian regresi linear sederhana, dapat ditulis dalam bentuk persamaan regresi sebagai berikut:

$\mathrm{Y}=11,727+0,739 \mathrm{X}$

Dimana keputusan dalam uji regresi linear sederhana dapat diketahui koefisien regresi $=0,739$ artinya setiap penambahan $1 \%$ nilai prasarana pariwisata maka nilai kunjungan bertambah 0,739 atau $73,9 \%$ dan dinyatakan arah pengaruh variabel prasarana pariwisata (X) terhadap peningkatan kunjungan wisatawan (Y) adalah positif, artinya jika pembangunan prasarana pariwisata meningkat maka kunjungan wisatawan akan meningkat pula. 


\section{REFERENCES}

Agusbushro, R. (2014). Analisis Kebutuhan Prasarana Dan Sarana Pariwisata Di Kawasan taman Nasional Bunaken Kecamatan Bunaken Kabupaten Kota Manado. Raden Agusbushro', V. H Makarau $^{2} \&$ Amanda Sembel ${ }^{3}$.

Fajriah, S. D. (2014). Pengembangan Sarana dan Prasarana untuk Mendukung Pariwisata Pantai yang Berkelanjutan ( Studi Kasus : Kawasan Pesisir Pantai Wonokerto Kabupaten Pekalongan ), 10(2), 218-233.

Hasibuan, M. (2016). Manajemen Sumber Daya Manusia. Jakarta: Bumi Aksara.

Henryk, S. (2013). Partisipasi Masyarakat Dalam Pembangunan Di Kelurahan Sungai Keledang Kecamatan Samarinda Seberang Kota Samarinda, 1(2), 612-625.

Ridwan, M. (2012). Perencanaan \& Pengembangan Pariwisata. Jakarta: Softmedia.

Sugiyono. (2013). Metode Penelitian Kuantitatif, Kualitatif dan R\&D. Bandung: Alfabeta.

Suchaina. (2014). Pengaruh Kualitas Sarana dan Prasarana Terhadap Peningkatan Jumlah Pengunjung Danau Ranu Grati. STKIP PGRI Pasuruan.

Taufik. (2016). Pengertian Wisatawan. Retrieved March 15, 2017, from https://taufikzk.wordpress.com/2016/02/01/pengertian-wisatawan/

Widayati, A. (2012). Bali Sebagai Salah Satu Destinasi Pariwisata Favorite Wisata Jepang. Universitas Indonesia.

Wijaya, I. (2014). Pengaruh Kunjungan Wisatawan, Jumlah Tingkat Hunian Kamar Hotel, dan Jumlah Kamar Hotel Terhadap Pendapatan Asli Daerah (PAD) Di Kabupaten Badung, Gianyar, Tabanan, Dan Kota Denpasar Tahun 2001-2010. E-Jurnal Ekonomi Dan Bisnis Universitas Udayana, 513520. 